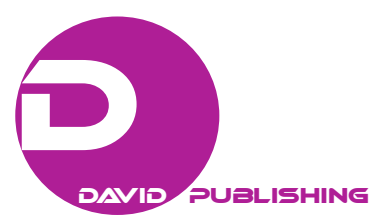

\title{
Slavery Act: Modification of the Hungarian Labour Code-Legal Analysis
}

\author{
Gábor Kertész \\ International Business School, Budapest, Hungary
}

\begin{abstract}
In the middle of December 2018, Hungary has suddenly appeared in the headlines of international news. Although marketing teaches that "all PR is good PR", as a lawyer, the author thinks it is worth examining the facts behind the catchy headlines well before making our business decisions. The news is based on the amendment of the Labour Code, which is called the "Slavery Act" in the media. The demonstrations and atrocities reported by the international media have broken out as a result of the interpretation of the amendment by some part of the media, which was recently adopted by Parliament. The President of Hungary promulgated the act when this article was completed. What does the new amendment say? Could an employee become a "slave" of the employer, or rather it would help people's prosperity by allow them to work more to earn more money? Considering the interests of the citizens/employees, can the choice between adoption or rejection of the law be the only possibility, does the new system also have a third possibility using the law's and the economy's own logic, or should only a small "fine-tuning" be implemented on the new system?
\end{abstract}

Keywords: labour law, working time frame, overwork, maximum working time

\section{Introduction}

In the middle of December 2018, Hungary has suddenly appeared on the headlines of international news. Although marketing teaches that "all PR is good PR", as a lawyer, the author thinks it is worth examining the facts behind the catchy headlines well before making our business decisions. In higher education, we teach the students on the first legal introductory courses that the published laws are presumably known to everyone. In reality, it is a fiction, but without this premise, the law cannot work. The demonstrations and atrocities reported by the international media have broken out as a result of the interpretation of the amendment by some part of the media, which was recently adopted by Parliament and promulgated by the President of Hungarian State as well. What does the new amendment say? Could an employee become a "slave" of the employer or rather it would help people's prosperity by allow them to work more to earn more money?

On 12th of December 2018, the Parliament of Hungary passed an act on "amending certain laws relating to the organization of working time and minimum rental rates for temporary agency work" (No. T/3628), which received the title "Slavery Act" from the opposition and during the legislative debate from one part of the media. In the following, the author will refer to it by the number of the bill or by the nickname stuck on it. Following the submission of the bill on 20th of November, an intensive and passionate debate soon emerged about the bill in the media and then in the Parliament. In Hungary, since the change of regime in 1989, it has

Gábor Kertész, Ph.D., professor, International Business School, Budapest, Hungary.

Correspondence concerning this article should be addressed to Gábor Kertész, H-1034 Budapest, Szőlőutca 35, Hungary. 
been the practice of the government to present the draft laws as a finalization of a preparatory process involving a ministerial proposal and an impact assessment, thus establishing a thorough explanation of the bill. However, the bill was not submitted by the Ministry of Labour, but by two individual parliamentarians. The parliamentary majority perceived the amendments of the opposition as obstructive technique and treated them accordingly. In this intense debate, no substantive and professional debate on the content of the bill was recorded in the minutes of the plenary session, only a political debate took place over a period of more than five hours. The statues and furnishing of the Chamber of the Parliament have long not seen such behaviour, but they have seen more drastic ones, than they have observed during the final vote on the bill. There are similar cases in the history of most democratic states. It is thought-provoking that there are still well observable red lines in front of the first rows in the chamber of the House of Commons in the British Parliament, which the Members were not allowed to cross during the debates, therefore they could no longer damage each other with swords worn by the deputies in the times of first drawing the lines.

In one's personality, intellect and emotion are both present at the same time. Therefore, however educated and intelligent people we are, there are situations when we react to a particular question with a strong emotional expression. However, after such an emotional outbreak, we can communicate or argue again on the basis of our logic, only if or opponent-due to our emotional outburst-does not get into a similar emotional state. The world press has conveyed several such cases over the past decade. There were some protracted protests at the time in front of the House of the Parliament as well. In the second half of the 19th century, the usage of firearm in the Chamber was not without precedent. As the impulses shrank, the debates could be mutilated in all cases and with logical negotiation an agreeable consensus could be reached for both sides.

The essence of the relevant law change can be concluded on the basis of the interpretation of various politically exposed people in the media and on statements from both the government and the opposition as follows: According to the government, the amendment allows employees to work more if they want to earn more; while the opposition says that the new rule will make an employee a quasi-slave who can be exploited to the extreme and will only receive the wages of the overtime after three years.

The debate has become a major issue in the Hungarian public life through media and has appeared on an international level. The following is a legal method in which the author is going to analyse the law that has been adopted and recently promulgated.

\section{Materials and Methods}

For analysis, draft law T/3628; the amendments proposed by the Legislative Committee T/3628/6; uniform proposal by the Legislative Committee T/3628/8; the text of the Labour Code in force on the day of the final vote are used; and the author uses the Directive 2003/88/EC of the European Parliament and of the Council, referred to by the bill as a compliance with EU law. The documents are not officially translated into English except for the Directive, so the quoted parts are the translations ${ }^{1}$.

\section{Results and Analysis}

In jurisdiction, it is particularly important to define and register the definitions clearly. In which way have the concepts and their definitions changed now?

\footnotetext{
${ }^{1}$ In the footnote, I will give the original Hungarian text.
} 


\section{The Working Day}

The definition "calendar day or uninterrupted 24 hours" has not changed, only the phrasing of the cause has changed from "the operation of the employer" to "job scheduling", in Section 87 of the Labour Code according to Article 2 of T/3628/8. This is not a significant change, since both the "interest of the employer" and the "job scheduling" are a matter of interest for the employer.

The concept of total daily working time, eight hours per day as defined in Article 92(1) of the Labour Code has not changed, as this has not been affected by the T/3628 bill.

The upper limit of weekly working time is 48 hours according to Article 99(2) of the Labour Code in accordance with Article 6(b) of Directive 2003/88/EC, which also limits working hours to 48 hours during seven consecutive days.

\section{The Rest Period}

In principle, we have so far known the rule that after six days of work one rest day should be scheduled. According to the rule till now, weekly rest days were allowed to be scheduled unevenly but after six working days a rest day had to be included, except for the cases when an employee's activity lasts for an uninterrupted period, an employee is engaged in shifts or seasonal activities, to whom there were no particular rest day guarantee regulations stated in the law, but such regulations could be determined by interpreting the law through its references. This could have been done by reading Article 105(3) and (4) of the Labour Code so far, where it is explicitly stated, that in the above-mentioned exceptions, minimum one rest day per month must be scheduled. Article 7 of T/3628/8 explicitly states this in Article 105(3) of the Labour Code.

\section{Overtime}

According to the current rule of Labour Code Article 109(1), 250 hours of extra working time per calendar year can be enacted for full-time workers. Article 8 of T/3628/8 adds that

On the basis of a written agreement between the employee and the employer-exceeding 250 hours-a maximum of 150 hours extra working time per calendar year (voluntary overtime) can be enacted. The employee can terminate the agreement at the end of the calendar year.

With the newly introduced concept of "voluntary overtime", based on the traditional logic of labour law one's primary concern could be - as we can see in the history of labour law-that an employee individually, independently is in a significantly less favourable bargaining position vis-à-vis the employer than he or she would be in organized circumstances; there could be a risk factor that the employer will persuade the employee to agree on an additional 150 hours of overtime upon the 250 hours of enacted overtime with some not unlawful force.

The agreement can only be terminated at the end of the calendar year. At first glance, this rule is necessary, for it allows termination of the agreement at the end of the working time frame, but we forget that the new rule raises the working time frame ${ }^{5}$ up to three years and the working time frame is not in synchronization with the calendar year, therefore it is completely irrelevant from the point of view of accounting that the termination of the agreement takes place at the end of the month, in the middle of the month or at the end of the year, but not

\footnotetext{
${ }^{2}$ Munkáltató múködése.

${ }^{3}$ Munkarend beosztása.

4 Önként vállalt túlmunka.

5 Working time frame: The unit of time during which full-time work (40 hours per week) per unit of time must be fulfilled.
} 
at the end of the working time frame. Therefore, if we were to assume that the legislature intended the employment to be terminated only at the end of the working time frame, then this intention could have been clearly described by the phrase "the agreement can be terminated only at the end of the working time frame".

\section{Working Time Frame}

According to the Article 93 of the Labour Code, the employer can also specify the working time to be performed by the employee in a working time frame. Working hours in the working time frame should be based on the duration of the working time frame, the daily working time and the general working schedule. In doing so, the public holidays which fall on otherwise working days according to the general working schedule shall be disregarded. According to the rule to date, the duration of the working time frame can be no more than 12 months or 57weeks, according to the provisions of a collective agreement. According to the modifications in Article 3 of $\mathrm{T} / 3628 / 8$, the collective agreement can set a working time frame of up to a maximum of 36 months.

Increasing the working time frame to 36 months raises questions, as Article 17 of T/3628/8 lays down compliance with the last paragraph of the second paragraph of Article 19 of Directive 2003/88/EC that "the reference period should be fixed in a maximum of twelve months". The EU law term of "reference period" concept corresponds to the Hungarian law term of working time frame.

Overall, is this change positive or negative from the employee's point of view?

1. When can the employee be enacted to work the most? The total weekly working time is 40 hours. There are 52 weeks in a year. In full-time employment, the employee is required to work 40 hours a week. The employer may enact 250 hours of overtime per year and in addition additional 150 hours overtime per year could be enacted through an individual agreement.

Mathematically, it means: $(40 \times 52=2,080)+250+150=2,480$ working hours per calendar year.

A non-derogating rule under Labour Code Article 99(1)(b), in accordance with Article 6(b) of Directive 2003/88/EC states, that an employee can be assigned to work for a maximum of 48 hours in any seven consecutive days. The maximum of 2,480 hours a year, divided into 52 calendar weeks, gives 47.69 hours, which means that overtime can be accomplished without prejudice to the Hungarian and EU rules on maximum weekly working time without increasing the weekly working time limit.

2. The 48-hour limit for the week is 2,496 hours per year, which means 416 hours of overtime, which is not permitted by $\mathrm{T} / 3628 / 8$. The number of working hours in one year has increased, but the maximum set by EU law (416 hours) has not been reached.

3. Considering that the working time frame can take up a period of 36 months (three years), there is a theoretical possibility to have a working time frame of 155 48-work-hour weeks and a "free week" for the employee.

2,480 (max. annual working hours) $\times 3$ (year)/48 (weekly working time) $=155$ (working week). The "free week" is, of course, in addition to the statutory paid leave.

4. In the debate on the "Slavery Act", it has been suggested in several occasions, that the employee will only receive the wage for overtime after three years, but the rules on the payment of wages have not been changed in the amendment, the Labour Code Article 136-137 and 154-158 on this subject are intact. According to these Articles, the wage must be paid monthly and retrospectively. In the case of uneven working time arrangements, if the employee is entitled to a monthly basic salary irrespective of the scheduled working time in the given month, he or she receives the monthly basic salary, in the case of hourly wages—unless otherwise agreed-the 
employer shall calculate and pay the wage of the employee on the basis of the number of working days according to the general working schedule governing the given month and the daily working time [Labour Code Article 156(1)(b)] $]^{6}$. This is therefore a theoretical possibility under statutory rules that has been in force since 2013, but no case has yet arisen in which the overtime fee would have been postponed until the end of the annual working time frame. In other words, the law gives the employee the opportunity to receive even wage even in the case of uneven working hours, as the work done and the paid wage are compensated by the time of the expiration of the working time frame. In the case of using a working time frame of longer than one month, there has always been a question that had to be solved with payroll-and this question will keep up until the working time frame remains longer than the payroll frequency-which is the following: If the employment terminates for any reason before the end of the working time frame, it is necessary to account for the actual work done and pay wages accordingly and then either the employer has to pay some difference, or the employee has to pay back the part of the wage received but not worked for.

5. The individual negotiation of "voluntary overtime", that appears as a new concept, however raises the possibility of the deterioration of the employee's bargaining position. The concept was included into the text as an amendment proposal during the debate on the bill. The original plan would have raised the amount of maximum overtime to be enacted by the employer from 250 to 400 hours.

6. The history of labour law clearly teaches in case of every country, that workers' representations have been able to obtain in every point of the contract much more favourable conditions for employees in negotiating a contract of employment, than when the employees individually negotiated. Therefore, the rule that employees agree individually with the employer in the case of voluntary overtime rather than through workers' representations is a risk that is undefinable for employees.

7. According to Labour Code Article 156(3) unaffected by this amendment, after the expiry of the working time frame, if the employee has received less wage than has been determined for the whole working time frame the difference shall be paid with the next month's wage.

8. In the second paragraph of the General Explanatory Memorandum to the Bill, the representatives who submitted it state, that according to their point of view, the role of collective agreement in the world of work has been limited since its entry into force of the current Labour Code, the transformation of statutory obligations into individual workplaces is in the interest of those involved in the employment relationship. The rules of the legal relationship should be left to the agreement of the subjects of the legal relationship. A risk factor that jeopardizes the interests of the employee is reflected in the new rule by the possibility, that the actual overtime done within voluntary overtime is paid subsequently. As a general rule, payroll accounting must be performed on the basis of the work actually carried out each month within working time frame; however, the correction of possible errors in the monthly salary account is mandatory only after the expiration of the working time frame, but the law allows the conclusion of an agreement with different content.

\section{Discussion}

From the above analysis, it can be seen that the amendments made by the "Slavery Act" have brought

\footnotetext{
${ }^{6}$ Egyenlőtlen munkaidő-beosztás esetében havibéres díjazás esetén a munkavállalónak—a beosztás szerinti munkaidő mértékétől függetlenül—a havi alapbére jár; órabéres díjazás esetén-eltérő megállapodás hiányában—a munkáltató a munkavállaló munkabérét az adott hónapban irányadó általános munkarend szerinti munkanapok számának és a napi munkaidőnek az alapulvételével számolja el és fizeti ki.
} 
forward positive rules from an economic point of view-both at national macro and corporate/individual employee micro level—but the philosophy, that with the exercise of self-reliance through the principle of individual autonomy entrusts the employee full issue of the voluntary overtime agreement completely, leaving out the workers' representations, potentially poses a risk to the interests of employees. Whether the interests of employees are actually going to be violated, or whether it is going to remain at the level of hypothetical risks, it cannot be answered right now, immediately after the adoption of the new law by Parliament.

According to the latest data of the Hungarian Statistical Office (KSH) in December 2018 (data release: 05/12/2018), unemployment in Hungary was 4.2\% in the 15-64 age group, the headcount of which is 6,546,490, which means 274,952 unemployed people nationwide. In contrast, according to the data collected at the same time, there were 53,605 vacant jobs at national level. Not going into the territorial and educational distribution of the unemployed population, it is worth noting that both the government and the employer side have been talking about labour-demand market for a long time. Comparing the data with other parts of Europe, we can see that among the working-age population, the employment-to-population ratio is $67.8 \%$ in the EU and fairly close 68.7\% in Hungary (KSH, 2018).

According to labour experts, while in the past, it was easy to find a new employee from a larger sample to replace a lost employee, today companies are much more hang on to their existing employees. Based on the employer's attitude of holding on their employees and on the fact that the sites of the same or similar production or service companies are typically at an accessible distance from the average employer, one may want to look at a perhaps novel thought experiment. In the past, until the 1990s, the pattern was that the employee should be stable, meaning that the employee is preferred to retire from the company where he/she started working as a junior employee. By now, this pattern has changed radically. According to International Labor Organization (ILO) statistics of 2014, the length of time spent in the same company was between 6.8 and 12.1 years in the EU Member States and an average of 8.8 years in Hungary (Berg, 2015). That means the employees have become more mobile. However, mobility can not only be achieved by leaving a job for another, but—as it has a decade-long tradition in Hungary—an employee very often has a second job, therefore he or she works for different employers. In order to be able to solve this without the problem of "bilocation", the employee has to work in both workplaces according to shifts. Calculating with 48 hours of working hours per a five-workdays-week, in accordance with the Directive, it is mathematically possible to possess two full time jobs parallel, with the help of a coordinated working time schedule and good transport.

Both EU and Hungarian legislations in force, only set the maximum working time that can be enacted on an employee by an employer, and it is not prohibited by law at any place, that a citizen/employee has two (or even more) jobs at the same time. Taking note of this practice, the Hungarian tax law has established special rules for the citizens to apply for due social benefits, which they can claim only on the basis of one employment relationship, but they can apply for it on the basis of one employment relationship.

In the growing number of jobs where there is a shortage of labour, the employee's bargaining position can also be exploited if the employee instead of accepting the voluntary overtime (or with parallel of it) takes a second job and persuades both employers to accept a coordinated work time schedule.

This employee friendly scenario obviously occurs only when in a given working field, there is a shortage of skilled employees and there is a competitive employer nearby needing the same qualified employees. In areas where there is an over-supply of labour, retraining or mobilising of the employees can be the solution, once again considering the situations individually. 
The explanatory memorandum of the bill supports the reference of the conclusion of voluntary contract for the voluntary overtime as opposed to collective agreement made by the workers' representation, stating that their role in Hungary is limited. This fact is supported by works on the political history of Hungary after the change of regime, supplemented by the fact that the leadership of many trade unions was intertwined with different political parties at different depths and thus often pursued activities representing party political interests, while the classical workers' representation was performed in a much smaller scale. There have been several examples of such actions, including successful ones, but it is also important to note that several of the successful actions were originally launched by civil movements unrelated to the unions and established directly to a specific case, which were later joined by the trade unions and lot of effort have been made by the organization to reach the goal.

\section{Conclusion}

The new law on working time frame in harmony with the EU law-respecting its regulations of the maximum length of the working time frame-has raised the working time frame by $60 \%$ in a way that this $60 \%$ raise cannot be obliged by the employer, but it has to be negotiated with the employees individually in a separated contract. Overtime undertaken under this additional contract can be accounted within a 36-month, three-year long working time frame, which can only be terminated by the end of the calendar year (end of calendar years within the working time frame).

The legislator entrusts the conclusion of this additional contract to the autonomy of the parties, without including them in the scope of the collective agreements to be concluded by the workers' representatives and the employer.

The new rule, which extends the working time frame to three years (36 months), based on the agreement of the parties, is not in line with the rules of EU law, which allows a maximum working time frame of 12 months.

\section{Epilogue}

When the author finished this article, the President of the Republic, promulgated the amendment of the "Slavery Act" on 20/12/2018 as the CXVI. Act of 2018. However, in this article, the author is not referring to the new law and its paragraphs, which are completely identical with the wording of proposal T/3628/8, but the author has retained the identification numbers of the final proposal of the version elaborated during the parliamentary procedure.

Following the promulgation of the law, the basic rule of the legal system taught to non-law students about the legal system arises, a fiction, according to which all legal entities are aware of proclaimed laws. This article is about the content of the new rule and about the new opportunities and risk factors that it allows. Weather this new rule is going to be accepted by society or political movements are going to be launched to change its content, it is not the matter of law, nor of economics, but of futurology.

\section{References}

Berg, J. (2015). Labour markets, institutions and inequality: Building just societies in the 21st century. Retrieved from https://www.ilo.org/global/publications/books/WCMS_314464/lang--en/index.htm

Directive 2003/88/EC. from https://eur-lex.europa.eu/legal-content/EN/TXT/PDF/?uri=CELEX:32003L0088\&from=EN 
Hungarian and EU acts.

KSH (2018). Statisztikaitükör, 5/12/2018. Retrieved from http://www.ksh.hu/docs/hun/xftp/idoszaki/mpf/mpf1809.pdf Legislation drafts.

T/3628. Retrieved from http://www.parlament.hu/irom41/03628/03628.pdf

T/3628/6. Retrieved from http://www.parlament.hu/irom41/03628/03628-0006.pdf

T/3628/8. Retrieved from http://www.parlament.hu/irom41/03628/03628-0008.pdf

1st Act of 2012 Hungarian Labour Code. Retrieved from http://njt.hu/cgi_bin/njt_doc.cgi?docid=143164.362248

116th Act of 2018. Retrieved from http://njt.hu/cgi_bin/njt_doc.cgi?docid=211818.362321 